\title{
The Replacement of the Terminal Bud in the Coco-nut Palm.
}

\author{
BY
}

\author{
T. PETCH, B.A., B.Sc., \\ Botanist and Mycologist, \\ AND \\ C. H. GADD, B.Sc., \\ Assistant Mycologist, Ceylon.
}

\section{With three Figures in the Text.}

$\mathrm{N}$ the valuable contribution to our knowledge of Bud-rot in coco-nuts by Messrs. Sharples and Lambourne in this Journal, vol. xxxvi, pp. 55-70, cases are described in which, according to the observations of the authors, it appeared that the terminal bud had been destroyed and that growth had subsequently occurred from a lateral bud. Assuming that deduction to be correct, the phenomenon would be parallel to the normal condition in dicotyledonous trees, in which the loss of the leader is generally followed by the development of shoots from lateral buds, one of which shoots may ultimately form a continuation of the original main axis.

As is well known, branching does not normally occur in the coco-nut palm. On the young palm, nothing develops in the leaf axils, while on the older trees each leaf subtends an inflorescence. Rare occurrences of branched coco-nut palms have been recorded, but, in view of the normal habit and structure of the tree, it is generally assumed that such cases arise from a division, probably accidental, of the terminal growing-point. No one appears to have had an opportunity of verifying that assumption, and it is doubtful whether such opportunity could ever happen, as, owing to the slow unfolding of the leaves, many months must elapse before the branching becomes evident. Instances of virescence, i. e. the conversion of the inflorescence into an axis bearing abnormal leaves, are not uncommon, but these abnormal inflorescences die, just as they would ultimately have done had they borne flowers.

Consequently, the idea that the terminal bud of the coco-nut palm may be destroyed, and be subsequently replaced by a lateral bud, is a novel one which, in the absence of complete evidence, can only be regarded as

[Annals of Botany, Vo1. XXXVII. No. CXLVII. July, 1923.] 
probable, if no other explanation of the phenomena observed is available. The object of the present note is to record a similar occurrence in Ceylon in which the origin of the apparently lateral growth was traced by dissection of the plant.

In March I 922 two specimens of diseased seedling coco-nut palms were received from the Galle district. The young unfolded leaves were withered and brown, and could easily be pulled out of the sheath. Springing from

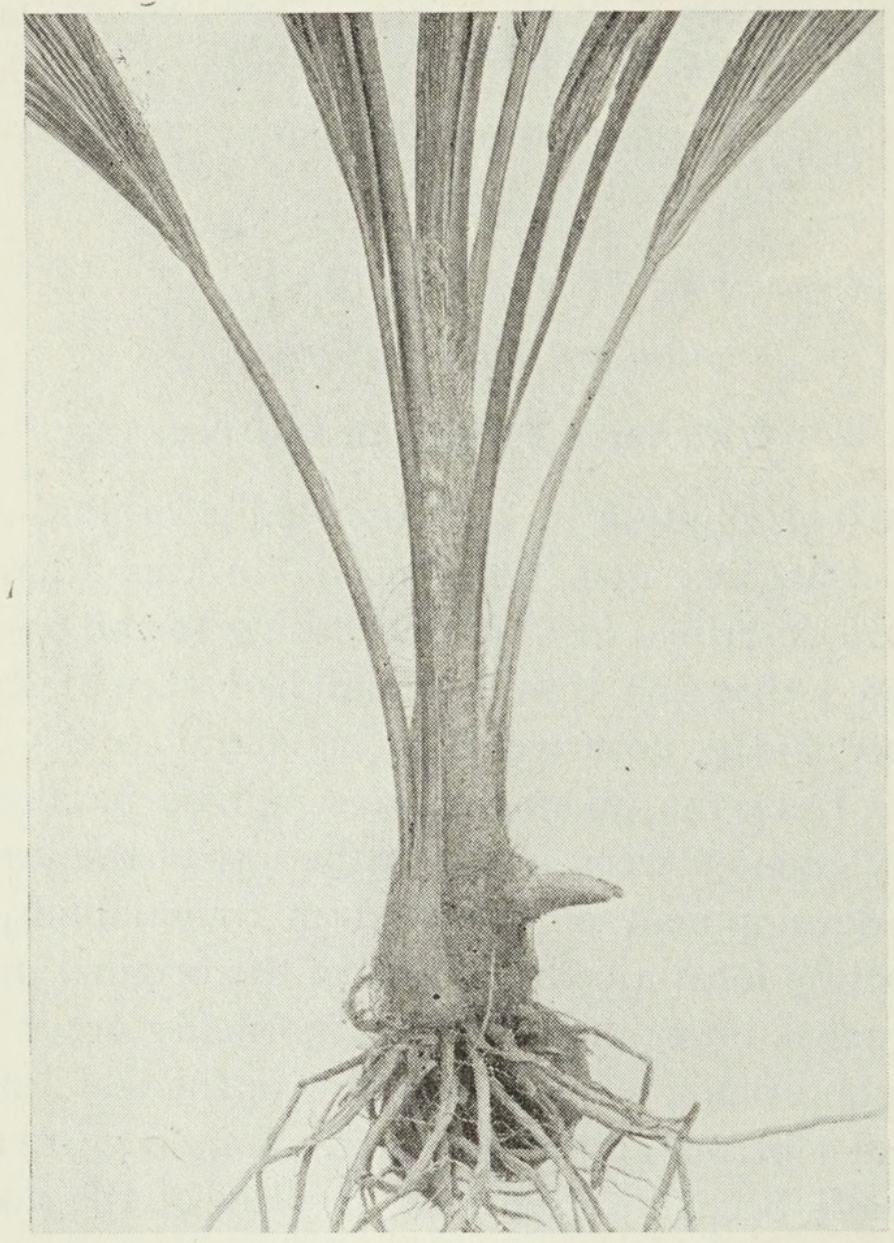

FIG. I. Seedling coco-nut palm with a 'lateral' bud. $\times \frac{1}{12}$.

near the base of the stem, however, was what appeared to be a healthy lateral bud. A photograph of one specimen as it was received is given in Fig. I. The withering of the central leaves and their easy withdrawal from the sheath, owing to a decay of their bases, suggested Bud-rot, but the formation of what appeared to be a new bud near the base of the palm was an abnormal condition in this disease in Ceylon.

On removing the external leaves it was found that a hole had been bored through the base of one of the young leaves as though by a large insect, possibly the rhinoceros beetle. A soft rot had occurred round the hole and had spread to the bases of the adjacent leaves. The rot at their bases had caused the withering of the leaves, and made it possible to pull 
them out easily from the sheath. In one case the rot had reached the central axis, but the bud itself was not damaged. In both cases, however, the direction of growth of the bud was changed from the vertical to the horizontal, and the buds had pushed their way through the leaf-bases to the exterior. A photograph of the palm with the leaves removed from one side is given in Fig. 2. This shows the curved bud and a rotting leaf-base immediately behind it. A drawing of the longitudinal section through the bud and axis is given in Fig. 3, from which it is evident that the bud, though projecting through the leaf-bases and apparently lateral in position, is the original terminal bud.

It may be concluded that a diseased condition of the central leaves causing them to fall over does not necessarily connote the death of the palm, i. e. it is not necessarily true Bud-rot. This conclusion was also reached by Sharples and Lambourne as a result of their inoculation experiments on coco-nut palms.

Sharples and Lambourne found that, as a result of inoculating coco-nut palms with a red pigmented bacillus, the central shoots of the inoculated palms became black and decayed, and ultimately fell over, as is common in Bud-rot cases. These palms eventually recovered in a peculiar manner. The authors give a figure showing the type of recovery, of which they say, "The central shoot has disappeared, but from the side of the bud below the remains of the central

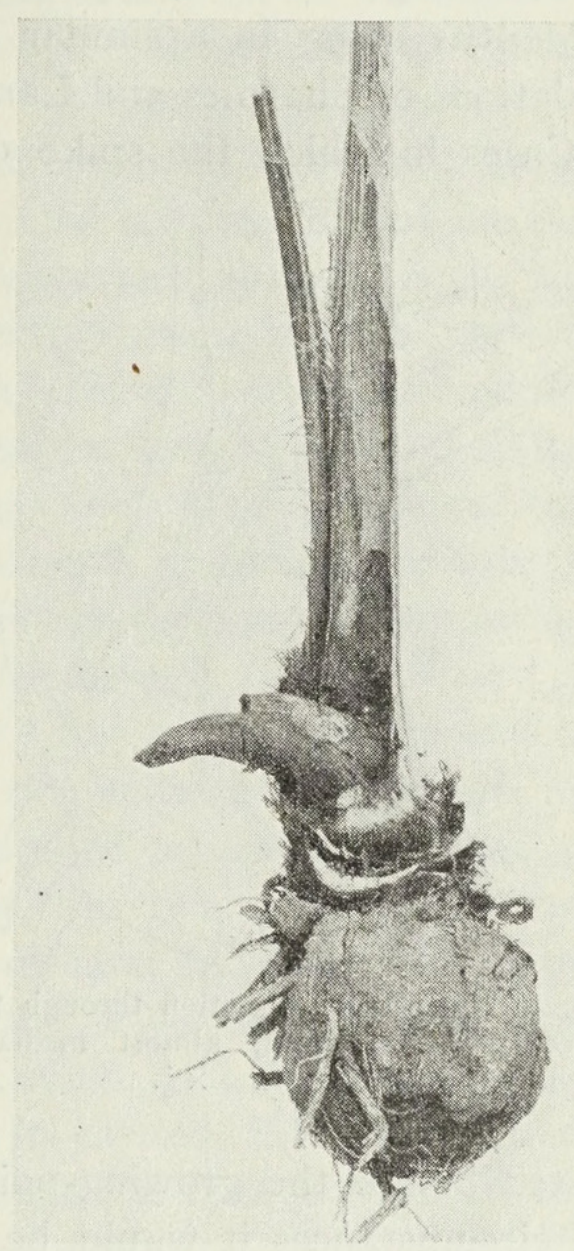

FIG. 2. The same, with the leaves removed from one side. $\times \frac{1}{9}$. shoot a lateral shoot is pushed out. The leaves comprising this lateral shoot were strangely aborted, the leaflets being very stiff and only partially developed. Growth of this lateral shoot continues and it takes the place of the central shoot.'

The figure given shows a young palm with a developing bud projecting from the side of the stem. It is similar in many respects to that given here in Fig. I, except that the bud is further developed, with young leaves expanded. The outer leaves of the buds of the Ceylon specimens were abnormal, having no leaf-blades and consisting solely of thick leaf-bases. It might therefore be expected that the further development of these buds 
would give the palms an appearance very similar to that illustrated by Sharples and Lambourne.

Moreover, the method of inoculation used by Sharples and Lambourne, though artificial, was in many respects similar to that by which the Ceylon palms had become naturally infected. They used a small gouge with which to bore into the tender central tissues in order to admit the infecting organism, whereas in the Ceylon specimens infection had followed the natural boring of a beetle or other insect. The Ceylon specimens may be regarded as being in a similar condition to that caused by the artificial inoculations of Sharples and Lambourne.

Cases in which the spike of unfolded leaves which terminates the

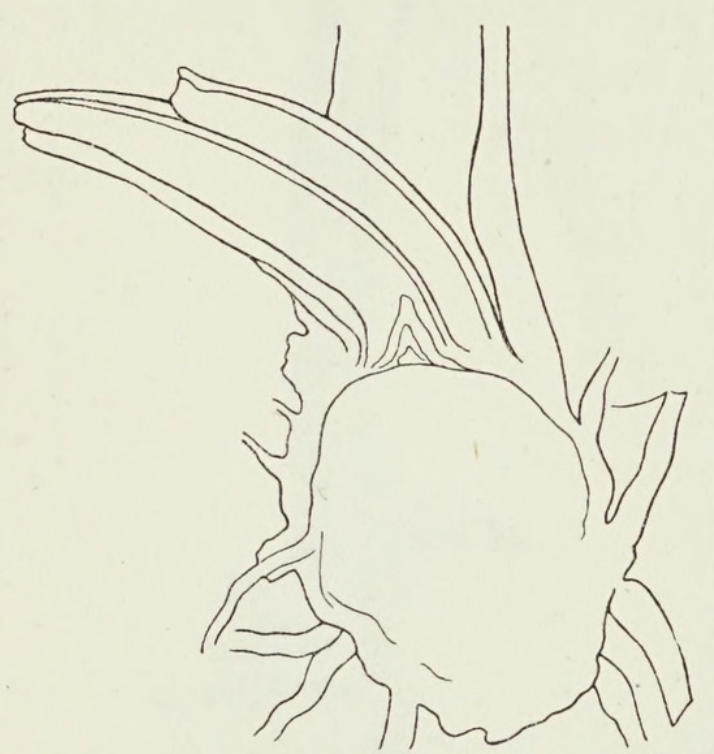

FIG. 3. Longitudinal section through the stem of the same plant, almost medially through the growing-point. $\times \frac{1}{3}$. crown of a coco-nut palm has decayed, while the growing-point has not been destroyed, have occurred in Ceylon on full-grown palms, though they appear to be very rare. In one instance it was found on examination that the apex of the embryonic tissue was blackened superficially, and the blackened surface had cracked into numerous areolae, the cracks being about half a millimetre deep. The developing leaf rudiments were distorted, and consisted of a short stout mid-rib, with the closepacked rudimentary folded leaflets along each side, the outer ends of the leaflets being also blackened. It is clear that in such cases the decay has been arrested before the growing-point has been seriously attacked, and under such circumstances it would be expected that further growth would take place in the direction of the original main axis. It has not been possible to verify the latter supposition, because this condition has only been discovered after the palm has been felled.

Sharples and Lambourne claim that the bud which appeared at the side of the stem in their experiments is truly a lateral bud, and not the original terminal which has changed its direction of growth. They conclude, inter alia, that-

'Owing to a very definite resistance exercised by the bud tissues of mature trees against infection, such organisms [i. e. saprophytic organisms inoculated into the bud tissues] in the absence of suitable conditions will not develop beyond a certain stage, marked by the death of the centrai shoot. If the central shoot dies, and the bud is invested externally with the invading organism, the bud tissues have the power of pushing out 
a lateral, by means of which growth is continued to take the place of the diseased central shoot' (p. 66).

'The prevailing idea that growth is no longer possible if the central shoot is killed must now be considered a fallacy, though it must be admitted that healthy growth is not immediate even if lateral shoots are produced' (p. 66).

'This cannot be regarded as any proof of the cause of the rotting of the bud tissues, no more than the death and falling of the central leaves in our experiments can be considered as proving the rotting of the central bud' (p. 68).

As regards what may be considered the most important conclusion from the purely botanical point of view, that the terminal bud of the coco-nut palm can be replaced by a lateral, evidence has already been adduced which would appear to afford another explanation of the phenomenon observed. It does not appear from their paper that Sharples and Lambourne dissected the palm in question and ascertained the origin of the supposed lateral bud. Further, as they intimate that they do not consider that the death of the central shoot in their experiments proved the rotting of the central bud, there would not appear to be any reason for supposing that the original growing-point had ceased to function.

The other conclusions depend mainly upon terminology, and on interpretations of the existing literature on the subject of Bud-rot. If the organism which causes a decay of the unfolded leaves is the same as that which causes a rot of the growing-point, the two phenomena must be regarded as different phases of the same disease, and the same name may be applied to both. But the decay of the leaf-spike only has not been regarded as 'Bud-rot' in coco-nuts in Ceylon. The statement, to which currency appears to have first been given in Ceylon, that the withering of the spike is 'the first indication of the disease' in true Bud-rot in the case of young palms cannot be interpreted as meaning that all cases of withering of the spike are cases of Bud-rot.

Sharples and Lambourne quote from Circular I5, vol. iii, of the Royal Botanic Gardens, Ceylon: 'The first indication of the disease in the case of young plants is the withering of the youngest unfolded leaf. This turns brown and can be pulled out of its sheath; it is then found to end in a soft brown mass.' But farther on in the same paragraph of that circular occur the words: "If the dying fronds are removed and the bud exposed, there will be found, instead of the white cabbage, a pale brown semi-liquid mass which becomes dark brown with age and possesses an odour resembling that of a tan-yard. In an advanced stage this rot includes the whole of the cabbage, and stops only when the woody portion of the stem is reached. Only the soft parts are affected. The roots and stem are quite healthy, but the destruction of the terminal bud necessarily causes the death of the tree.' 


\section{Petch and Gadd.-The Replacement of the Terminal Bud.}

Johnston, also quoted by Sharples and Lambourne, stated: "The common name of the disease, Bud-rot, well describes its nature, for in its acute or advanced stage the bud of the tree, i. e. the growing-point in the centre of the crown, is affected by a vile-smelling soft-rot which destroys all the younger tissues.'

It will be evident that the term 'Bud' is employed in both the foregoing extracts to denote the actual growing-point; and from the third quotation from Sharples and Lambourne's paper it would appear that the latter authors use the term in the same sense. The 'fallacy' that growth is no longer possible if the central shoot is killed is non-existent. The opinion which is generally held is that growth is no longer possible if the growing-point is destroyed. Before abandoning the prevailing idea as a fallacy, further evidence must be adduced, in view of the Ceylon examples, to show that, in the condition caused by artificial inoculations, the bud is truly a lateral, and not the further growth of the original terminal after a temporary arrest caused by the invading organisms.

\section{REFERENCES.}

Johnston, J. R.: The History and Cause of the Coco-nut Bud-rot. U.S. Dept. of Agriculture, Bureau of Plant Industry, Bulletin No. 228 (1912).

Petch, T.: Bud-rot of the Coco-nut Palm. Circulars and Agricultural Journal, Royal Botanic Gardens, Ceylon, iii, No. I5 (1906).

Sharpies, A., and Lambourne, J.: Observations in Malaya on Bud-rot of Coco-nuts. Annals of Botany, xxxvi, pp. 55-70. 


\section{$2 \mathrm{BHL}$ Biodiversity Heritage Library}

Petch, T and Gadd, C. H. 1923. "The replacement of the terminal bud in the coco-nut palm." Annals of botany 37, 445-450.

https://doi.org/10.1093/oxfordjournals.aob.a089858.

View This Item Online: https://www.biodiversitylibrary.org/item/270686

DOI: https://doi.org/10.1093/oxfordjournals.aob.a089858

Permalink: https://www.biodiversitylibrary.org/partpdf/319095

\section{Holding Institution}

New York Botanical Garden, LuEsther T. Mertz Library

\section{Sponsored by}

BHL-SIL-FEDLINK

\section{Copyright \& Reuse}

Copyright Status: Public domain. The BHL considers that this work is no longer under copyright protection.

This document was created from content at the Biodiversity Heritage Library, the world's largest open access digital library for biodiversity literature and archives. Visit BHL at https://www.biodiversitylibrary.org. 